\title{
Value Chain Analysis of Potato: The Case of Sheka Zone, Southwest Ethiopia
}

\author{
Benyam Tadesse $^{1^{*}}$ Fayera Bakala $^{2}$ \\ $1^{*}$ Mizan-Tepi university, College of Agriculture and Natural Resources, department of Agricultural economics \\ ${ }^{2}$ Mizan-Tepi University, College of Agriculture and Natural Resources, department of Natural Resource Management
}

Received: April 9, 2018; Accepted: April 19, 2018; Published: April 25, 2018

*Corresponding author: Benyam Tadesse, Mizan-Tepi University, College of Agriculture and Natural Resources, E-mail: tadessebenyam7@gmail. com

\begin{abstract}
The study was undertaken with the objective of identifying potato value chain actors, assessing profitability of actors, marketing margin and extent of value addition in the study area. Information was gathered from 193 potato producers, 7local traders, 7 wholesalers, and 8 retailers. The survey result indicated that $27.94 \%$ of total farmland was allocated for potato production. The average yield of Potato in Sheka was 108qt/ ha. The major potato value chain actors were input suppliers, producers, commission agents, local traders, wholesalers, retailers and consumers. Potato producers in Masha district added $10.537 \%$, Local traders were responsible for $25.603 \%$ of value addition while wholesalers and Retailers add about 29.89 and $33.39 \%$ of the value respectively. Creating sustainable value chain development by accessing new market centers and organizing cooperatives was vital for value chain producers in the study area.
\end{abstract}

Key words: Marketing Margin; Profitability; Value Chain; Value Chain map; Value Addition;

\section{Introduction}

In Africa, there is large potential for improvements in agricultural production and market development since Africa has more than half of the world's uncultivated but agriculturally suitable land and has scarcely used its extensive water resources [1]. Despite the large potential for improvements in agricultural productivity and market performance in Africa, especially given rapid overall economic growth, evidence on changes in domestic food value chains in Africa is still limited, possibly due to a lack of accurate and reliable data [2].(Figure 1)

Value chain refers to the full range of activities that are required to bring a product (or a service) from conception, through the different phases of production, to delivery to the final consumer and disposal after final use [3]. Analysis of the value chain is needed to obtain knowledge that can be applied to upgrade value chain activities. Several scholars have recognized that more attention is required to upgrade agricultural value chains to increase quality-based competitiveness of domestic agricultural produce, thereby improving food security and contributing to poverty alleviation [4]. It defined a food value chain as "the full range of farms and firms and their successive coordinated value-adding activities that produce particular raw agricultural materials and transform them into a particular

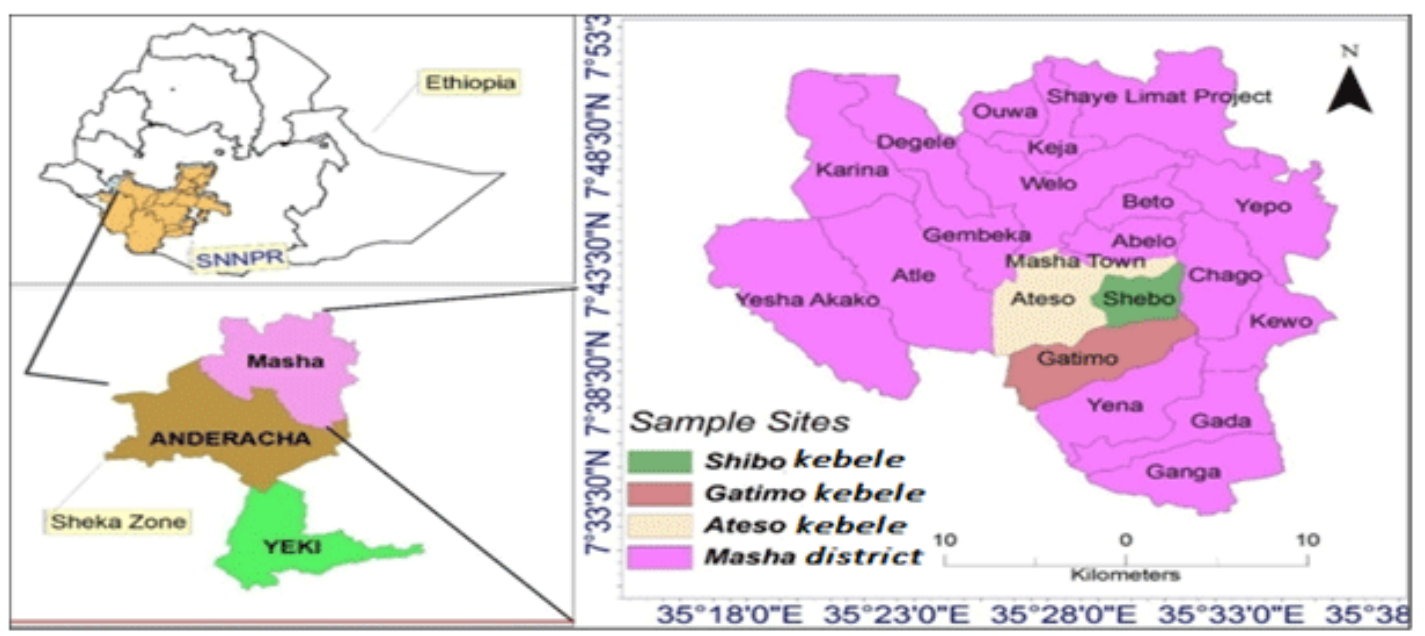

Figure 1: Location of study area 
food product that are sold to final consumers and disposed of after use."The actors typically found in a value chain include input suppliers, farmers, processors, transporters, collectors, wholesalers, retailers and the final consumers. These operators in the chain are linked by a series of trade relationships that take the product from producers to final consumers. A well-functioning value chain where actors mutually support themselves is capable of improving competitiveness of the entire value chain, from the time the produce leaves farm gate until it arrives to the hands of a satisfied consumer.

In Ethiopia, Root crops like potatoes, sweet potatoes and taro/ Godere are among the major root crops that are consumed in the country. The economic importance's of these crops prompt the peasant farm holders to grow many of the root crops. Root crops covered nearly $13.12 \%$ of the area under all Belg crops in the country [5]. According to the same source, Potatoes accounted for $81.74 \%$ of the total root crop area cultivated and $83.66 \%$ of the total root crop production in Ethiopia. That means the total area covered by potato was $296,577.59$ ha and $36,576,382.69$ qt of production in 2015/16 production season. Potato has been considered as a strategic crop by the Ethiopian government aiming at enhancing food security and economic benefits to the country [5]. As the population grows rapidly, increased productivity of potatoes can improve the livelihood of smallholder potato producers and is required to meet the growing demand [6]. About $70 \%$ of the country's available agricultural land is located at an altitude of 1800-2500 $\mathrm{mm}$ which is suitable for potato production [7]. In addition, potato is regarded as high-potential food security crop because of its ability to provide a high yield of high-quality product per unit input with a shorter crop cycle than major cereal crops like maize" [8]. Currently, many improved varieties of potato are disseminated by research centers, cooperatives and private suppliers to smallholders and this contributed to the improvement and expansion of potato production in Ethiopia.

Most literature and research in the past has focused on potato production and marketing. However, there is little evidence on the overall mapping of value chain actors. Therefore, this study was aimed in analysis of potato value chain in Sheka zone of southwest Ethiopia. The study result provided information on the value chain analysis of potato( Figure 2), help as an input for generating demand driven technologies of production and marketing and can also be used as a base for further detailed studies of potato in southwest Ethiopia and as a source of literature review for researchers. Therefore, this study was conducted with the objective of Value chain analysis of Potato specifically:-

\footnotetext{
$\sqrt{ }$ Potato value chain mapping

$\sqrt{ }$ Value chain performance along Actors

$\sqrt{ }$ Level of value addition in potato value chain

$\sqrt{ }$ Potato value chain constraints
}

\section{Materials and Methods \\ Description of study area}

This Study was conducted in Masha district of Sheka zone of South Nation and Nationalities Region (SNNPR) which located at $700 \mathrm{~km}$ to southwest of Addis Ababa. The district receives mean annual rain fall about $2000 \mathrm{~m}$ and its mean monthly temperature ranges between $18-21$ oC. Total area of the district is $217,527.15$ hectare with the total population of 40,810 , of which $49.3 \%$ are male and the remaining are female population. The area is known for its potato production potential. From 19 rural kebeles of the district the study was conducted in 3 kebeles viz., Gatimo, Atiso and Shibo.

\section{Data source and instruments}

In this study both primary and secondary data sources were used. Primary data were collected via household survey, focus group discussions, key informant interviews, field observations, and market assessment. Questionnaires were prepared independently for each actors of potato value chain. Additionally, individuals from different sectors as well as the local people who have knowledge and experience about potato production and marketing was selected as key informants and interviewed on the issues related to potato production and marketing. Data were also collected from traders and commission agents.

\section{Sampling procedure}

Preliminary information concerning study area was obtained from District agricultural office to get important information to select study kebeles. In this study, three-stage sampling technique was followed. In first stage potential worded as for potato production and marketing was purposively selected. At the second stage, among the 19 Kebeles of worded as, 3 Kebeles was again purposively selected based on the intensity of production and marketing of potato. In the third stage, household heads producing potato was selected randomly for the interview from three Kebeles. Thus, using the household list, 193 household heads was selected randomly for interview (Table 1). Besides to producers; 7 local traders, 8 retailers, 5 wholesalers and 5 commission agents were selected for interview using snowball method.

\begin{tabular}{|c|c|c|c|}
\hline \multicolumn{4}{|c|}{ Table 1: Sample size distribution in the sample rural kebeles } \\
\hline Kebeles & Total number of households & Sample size & Percent \\
\hline Gatimo & 116 & 60 & 31.09 \\
\hline Shibo & 108 & 56 & 29.02 \\
\hline Atiso & 149 & 77 & 39.9 \\
\hline Total & 373 & 193 & 100 \\
\hline
\end{tabular}

\section{Data analysis}

Descriptive statistics were used to analyze the data collected from potato producers and traders. These methods of data analysis refer to the use of percentages, means and standard deviations. In addition Value chain analysis frameworks developed by [3] were 
employed to Map potato value chain.

\section{Value chain analysis}

The following four steps of value chain analysis were applied to this study:

1. Mapping the value chain to understand the characteristics of the chain actors and the relationships among them, including the study of all actors in the chain, of the flow of potatoes through the chain, of employment features, and of the destination and volumes of domestic and foreign sales.

2. Identifying the distribution of actors' benefits in the chain. This involves analyzing the margins and profits within the chain and therefore determined who benefits from participating in the chain and who would need support to improve performance and gains.

3. Defining upgrading needed within the chain. By assessing profitability within the chain and identifying chain constraints, upgrading solutions could be defined. These may include interventions to: (i) improve product design and quality and move into more sophisticated product lines to gain higher value and/or diversify production; (ii) reorganize the production system or invest in new technology to upgrade the process and enhance chain efficiencies; (iii) introduce new functions where in the chain to increase the overall skill content of activities; and (iv) adapt the knowledge gained in particular chain functions in order to redeploy it.
4. Emphasizing the governance role. Within the concept of value chain, governance defines the structure of relationships and coordination mechanisms that exist among chain actors. By focusing on governance, the analysis identified actors that may require support to improve capabilities in the value chain, increase value added in the sector and correct distributional distortions. Thus, governance constituted a key factor in defining how the upgrading objectives could be achieved.

\section{Results and Discussion}

\section{Value chain analysis of potato}

Value chain mapping enables to see the flow of the product from conception to end consumer through various actors. It also helps to identify the different actors involved in the value chain system, and to understand their roles and linkages. Potato value chains cover all activities from input supply, production, processing, wholesale and retailing to the final consumer [9].

\section{Potato value chain map in the study area}

The value chain map highlighted the involvement of diverse actors who are participated directly or indirectly in the value chain. [10] Classified value chain actors in the agricultural sector as direct and indirect. Direct actors are commercially involved in the chain (input suppliers, producers, processors, traders, retailers, consumers) and indirect actors provide financial or non-financial services or support the functioning of value chain (bankers and credit agencies, business service providers, government, researchers and extension agents.

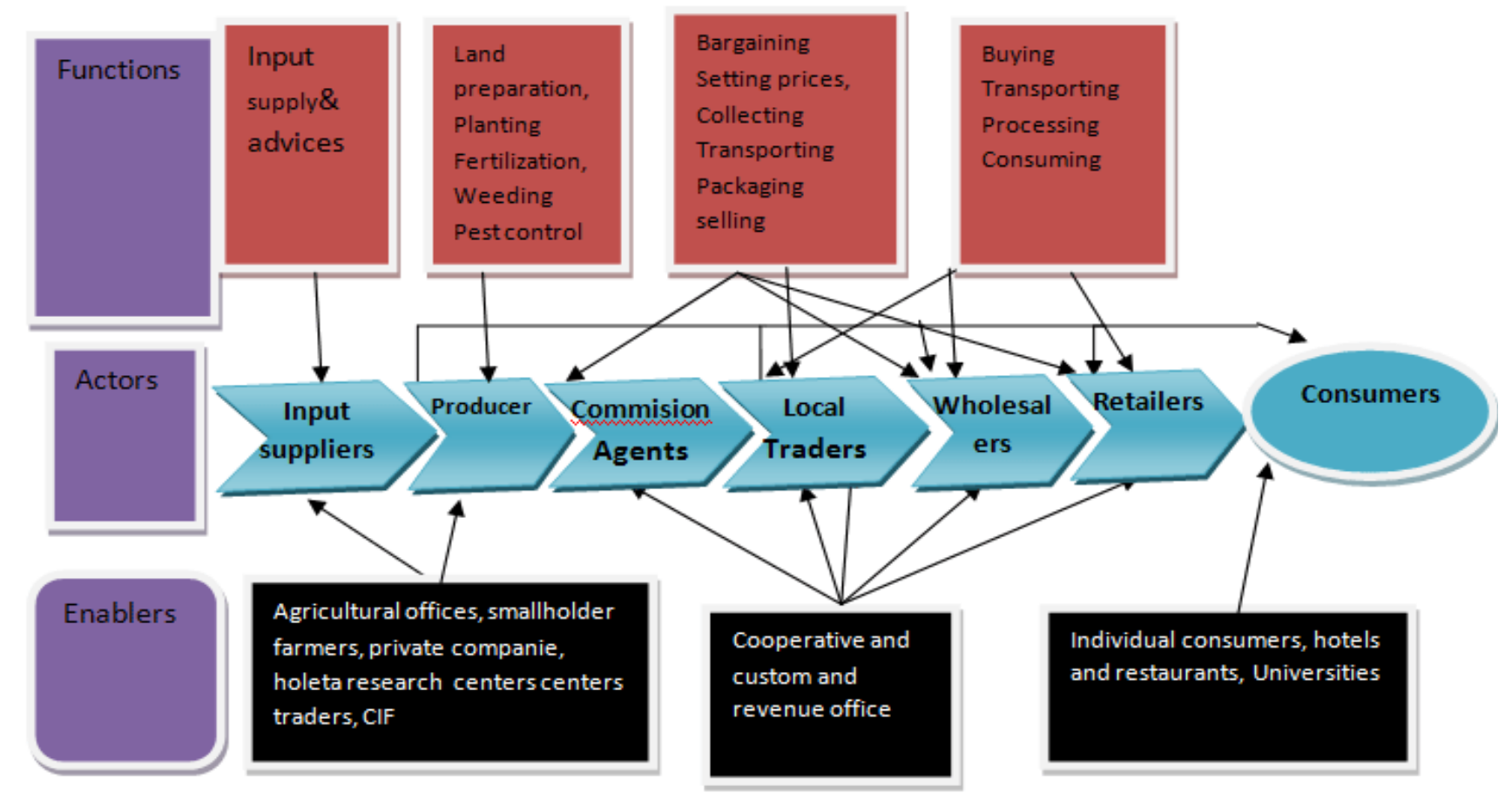

Figure 2: Value chain map of potato in Masha district 


\section{Primary actors}

The primary actors in potato value chain in Masha district were seed and other input suppliers, farmers, traders and consumers. [11] Identified the primary actors in red pepper in Abshige Worded as producer (farmers), local collectors, wholesalers, retailers, processors and final consumers of the product. But in potato value chain in the study area there were no processors. As product moves along different value chin routes each actor adds value. Functions performed by potato value chain are described here below.

I. Input suppliers: There were many actors engaged directly or indirectly in agricultural input supply in the study area. These include Masha district office of agriculture, seed multiplying centers, private traders, cooperatives and farmers. These input suppliers provide potato seeds, fertilizers as well as other pesticides and herbicide chemicals. Potato producers use seed from different sources including government, local farmers, cooperatives, traders and own production. Of which majority of producers obtained potato seed from their own production (29.5\%) and local farmers (25.4\%) which are followed by traders (16.1\%). In Hulla and Shashemane Worded as, 54\% and 48\%, respectively, of the sampled producers used their own seed for potato production. The remaining producers got potato seed from government and cooperatives that supplied improved seeds.

There is insufficient supply of certified seed to the extent that farmers almost entirely depend on informal seed sources (Table 2). Informal seed sources include positively selected and farm-saved seed, seed from local markets and seed purchased from neighbors and relatives. The main source of seed for most farmers is small seed tubers saved from the previous harvest [12]. It was identified that there are problems related to input supply including high price of seed and irregular and lack of on time supply expected time and quality problem. Even there was a situation that traders purchased matured potato from producers and store somewhere else for a particular time and supply it as improved seed for producers during production season; producers buy perceive it as was improved seed repurchase same product.

Table 2: Seed sources of respondents

\begin{tabular}{|c|c|c|}
\hline Seed sources & Frequency & Percent \\
\hline Government & 25 & 13 \\
\hline Local Farmers & 49 & 25.4 \\
\hline Cooperative & 3 & 1.6 \\
\hline Own production & 57 & 29.5 \\
\hline Traders & 31 & 16.1 \\
\hline Government and Farmers & 28 & 14.5 \\
\hline
\end{tabular}

II) Producers: The average land holding size of producers in the study area was about 3.15 hectare per household. Of these were potato growers who perform different activities from potato production through marketing. The major value chain functions that vegetable growers perform include planting, fertilization, weeding, pest/disease controlling, harvesting, post harvest handling and transporting to selling areas. Potato growers are the major actors who perform most of the value chain functions right from farm inputs preparation on their farms or procurement of the inputs from other sources to post harvest handling and marketing [7]. The average age of potato producers was 38 years, while their average family size was 7 . Regarding the education level of potato producers, averagely had 5 years of schooling. Producers had averagely 7 years of experiences in potato production and marketing. The mean distance from the nearest market center of producers in the study area was approximately about $5.5 \mathrm{~km}$.(Table 3)

\begin{tabular}{|c|c|c|c|}
\hline Table 3: Sources of inputs for Potato production \\
\hline \multirow{2}{*}{ Inputs } & Source of inputs & Frequency & Percent \\
\hline \multirow{2}{*}{ Fertilizer } & District office agricultural & 165 & 85.5 \\
\hline \multirow{2}{*}{ Herbicide/pesticides } & Local market & 20 & 10.4 \\
\hline & Cooperatives & 8 & 4.1 \\
\hline & Listrict office agricultural & 10 & 5.2 \\
\hline & Local market & 139 & 72 \\
\cline { 2 - 4 } & Cooperatives & 4 & 2.1 \\
\hline
\end{tabular}

About 0.57 ha/household were allocated for potato production. This area is less than the portion of farmland area allotted for potato production in Sinan (0.74ha/household) district in Amhara Regional and in line with the finding of Sol grows Plc (0.56ha/household) around Bishoftu area in Oromia regional state in 2012/2013 production season [13]. However, the land allocated for potato production is higher than the average estimated by [7] for Tigray ( $0.28 \mathrm{ha})$ and SNNPR $(0.45$ ha) per household. This difference could be due to the dominant potato cultivation system in the study areas [12]. All interviewed respondents were engaged in potato production with an annual average production of 10.26 tonnesper household. Moreover, the average potato yield is estimated to be 10.26 tonnesper household or (102.6 qt/household) and this finding is in line with the national average (8-10 t/ha). Contrary to this finding, yield per hectare in Sol grow contract farmers around Bishoftu area was higher than the national average as there was support in input supply and technical advice. However, per hectare productivity in Sinan (69 quintals per hectare) which was less than productivity of masha district but the yield produced at Sol grow (148 quintals per hectare) is in line with the findings (Kassa, 2014).The result in masha district was consistent with the finding of (Bezabih and Mengistu, 2011 which is Shashemane (143 quintals per hectare), and higher than that of Hula (104 quintals per hectare), SaesiTsaeda Emba (75 quintals/hectare), Atsibi-Wonberta (84 quintals per hectare)) are far less than masha productivity. (Table 4) 
Table 4:Socio demographic characteristics of producers.

\begin{tabular}{|c|c|c|c|c|}
\hline Variables & Minimum & Maximum & Mean & Std. Deviation \\
\hline Age & 20 & 63 & 38 & 10.0626 \\
\hline Education level & 0 & 12 & 5 & 3.174 \\
\hline $\begin{array}{c}\text { Distance from } \\
\text { market }\end{array}$ & 1 & 12 & 5.5 & 2.7274 \\
\hline Experience & 1 & 27 & 7 & 4.3455 \\
\hline Total family size & 1 & 12 & 7 & 2.0581 \\
\hline
\end{tabular}

Most farmers produce potatoes twice a year due to bimodal rainfall patterns in the study area. This is in line with the finding of [12]. The first round is from October to January, the second round is from February to May. However, the number of producers involved in potato production in these seasons varies. Majority (about 69.43\%) of the farmers engaged in potato production biannually. The remaining $24.78 \%$ and $12.44 \%$ were produced potato in the second and first round, respectively. Offseason potato production is not experienced in the study area. All producers were highly dependent on rainfall for potato production. This limits profitability in potato farming activity. (Table 5) showed that producers use both local and improved seeds as well as first and second generations of improved seeds in potato production. In addition locally known potato seed called "Gawasa" was used. While the remaining producers use improved potato seeds such as Jalane, Gudene and Beletu that are supplied from West Shewa Zone, Jeldu District.

Table 5: Potato seed sources and production seasons/rounds

\begin{tabular}{|c|c|c|c|c|c|}
\hline \multirow{2}{*}{ Respondents } & \multicolumn{2}{|c|}{ seed type in production } & \multicolumn{2}{c|}{ Production rounds } & \multirow{2}{*}{ 1st and 2nd round } \\
\cline { 2 - 5 } & Local seed & Improved seed & 1st round & 2nd round & \\
\hline Frequency & 135 & 58 & 48 & 24 & 120 \\
\hline Percent & 69.95 & 30.05 & 24.87 & 12.44 & 62.69 \\
\hline Cumulative \% & 69.95 & 100 & 37.31 & 100 \\
\hline
\end{tabular}

The yield and quantity supplied by respondents who used local and improved variety seed were vary. Annual mean of potato produced by producers who used local seeds were less than that of the respondents who used improved seeds. Similarly, annual mean of potato produced by producer who used only improved variety exceeds that of the producers who used combination of improved and local seeds. Farmers do not store potato after harvesting. The main reasons farmers do not store their potatoes are: a) the immediate cash needs at harvest time, b) the dependency on traders who may only come to buy potatoes during harvest periods, and c) consumers who are used to buying freshly harvested potatoes and often pay a lower price for 'stored' potatoes [12].
II) Traders: In this study trader refers to Commission Agents, local traders, retailers and wholesalers. As indicated in (Table 6) the average age of local traders; retailers and wholesalers were 31.43, 29.13 and 35 years, respectively. Local traders, retailers and wholesalers averagely have four family members. Averagely, wholesalers were more experienced ( 4.2 years) as compared to local traders (2.71 years) and retailers (2 years). Similarly, wholesalers had higher education level, while retailers have lower. The initial working capital of local traders, retailers and wholesalers were 6500.14 Birr, 359.38 Birr and 21928 Birr, respectively, but the respective current working capital were 59000 Birr, 3410.34 Birr and 65034 Birr.

Table 6: Socio demographic characteristics of traders

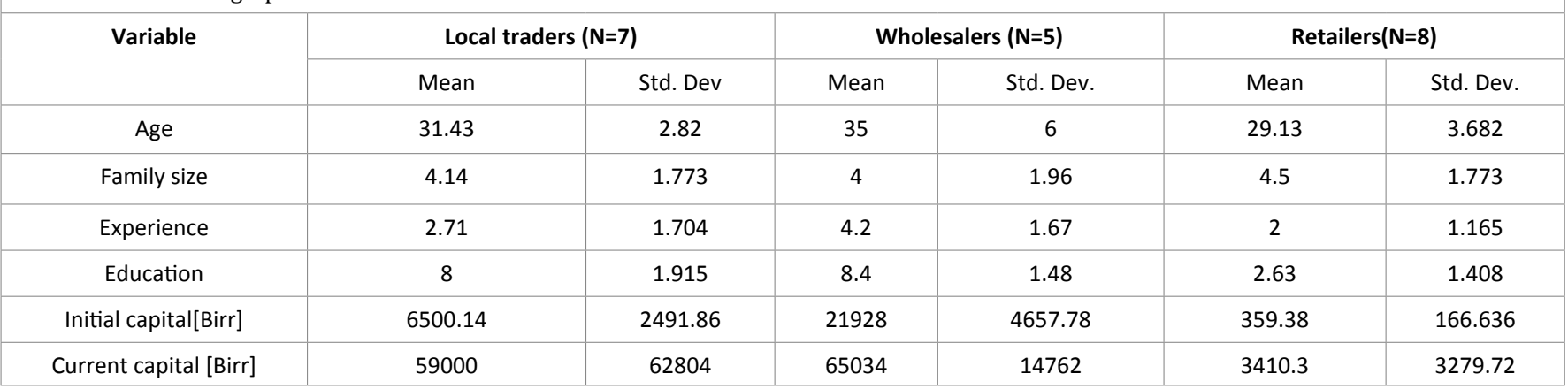

Commission men: They were actors who usually granted broad powers by those who consign goods to them. These actors play crucial role in potato marketing system by facilitating potato transaction and linking producers with other actors. These actors were working for local traders in the study area. They move down to communicate with producers and set selling prices for potato as far as possible. They offer quick and readily information regarding potato marketing system. They also play an important role in linking up farmers to market and other stakeholders of the commodity chain while the probability of market accession 
of farmers is limited. They sometimes go beyond facilitation of transaction and tend to control and fix prices, create price symmetry and make extra benefits from the process in addition to convincing the producers to sale their produce at the prices set by traders. They do not follow proper business conduct and as a result they constrain the marketing system sometimes. For instance, in the study area if the potato stayed one day at farm gate or home after harvested they call it bulti and in the next day the price will reduce by half.

Local Traders: All interviewed traders were Masha town dwellers. They served as potato buyers as well as input raw input suppliers. They are somewhat strong financially as well as management know how in all aspects of the business activity in relative with actors of this chain. They purchase potato from producers directly by physically and by commission men. Local traders have opportunities to sell their potato directly to wholesalers and retailers. Local traders have a great role in the transaction of the potato production from farmers and they are price makers at all frame gate transaction in the study area. The coupled effect of excess supply and perishable nature of potato obliged producers to sell at prices determined by local traders or commission men.

Wholesalers: They are well equipped with marketing facilities- transport, storage, and communication and with functionaries like commission men, weigh man, etc. according to information from key informants wholesalers come to study site from Tepi, Mizan- Aman, Jimma, Gambella and Addis Ababa to purchase potato. The major transaction takes place between local traders and wholesalers (transaction of potato takes place normally in bulk).

Retailers: They are actors that sell potato in small quantity as per the consumer's requirements. Retailers' activities in potato marketing system in the study area include buying, transporting to retail areas, and selling to consumers. They are key actors and last link between producers and consumers. Most of retailer bought potato from wholesalers and resold to urban consumers. Sometimes they could also directly buy from the producers.

Consumers: Households, restaurants and institutions were identified as potato consumers. As information from key informants, potato outputs were transported Gambella, Metu, Gore, Mizan-Aman, Addis Ababa and Jimma (sometimes), sold to processors (Hotels and Restraints).

\section{Support providers (Indirect Actors)}

Support service providers are essential for value chain development and include sector specific input and equipment providers, financial services, business management services, and market information access and dissemination, technology suppliers, advisory service, etc. In the study areas, there are many institutions supporting the potato value chain. The most common support providers are Agricultural offices, private companies; research centers traders, Cooperative and custom and revenue office, Universities.

\section{Potato market channels}

Six marketing channels were identified (indicated below) for potato marketing in the study area.

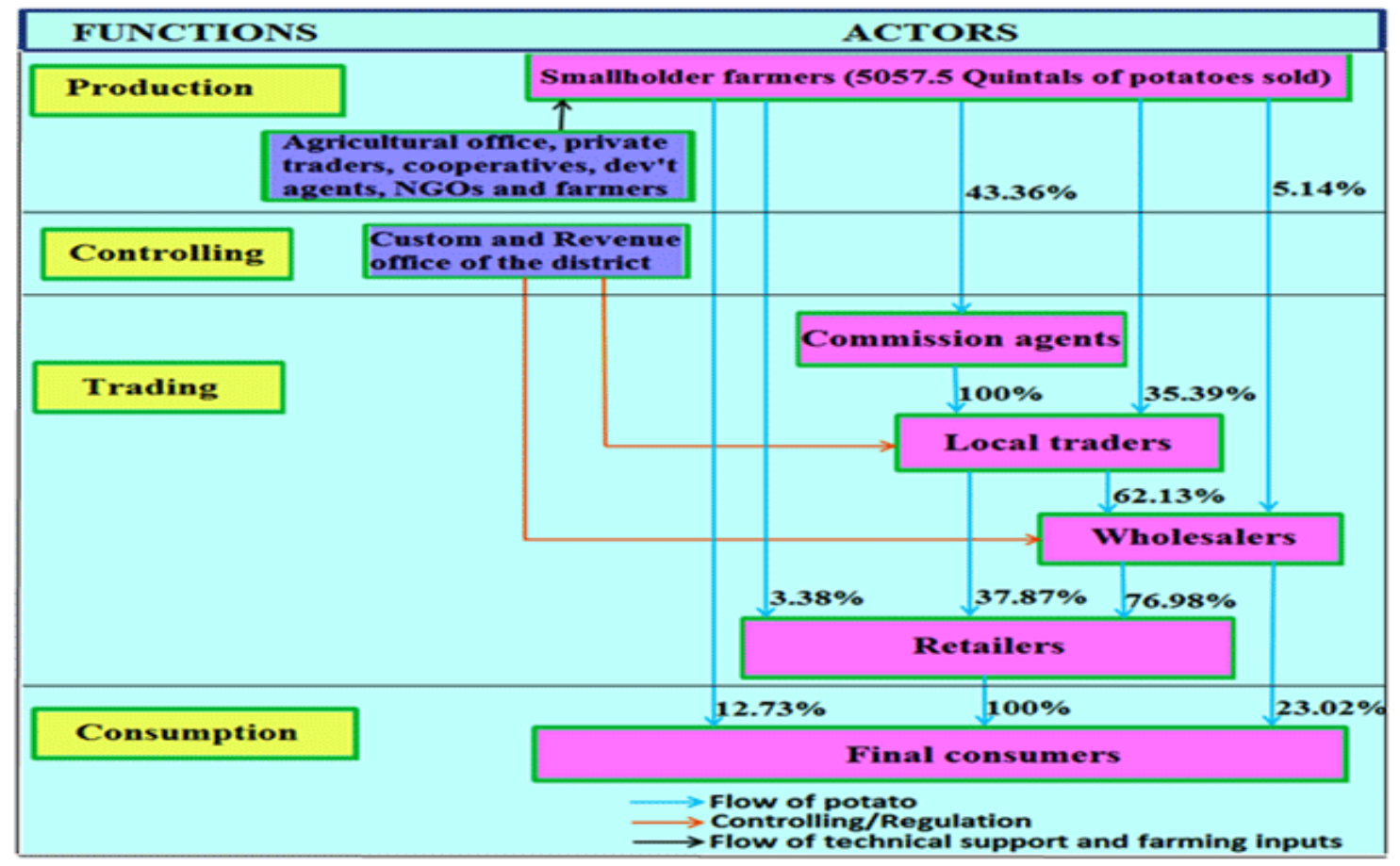

Figure 3: Potato market chain 


\section{Marketing I: Producers $\rightarrow$ Consumers}

Marketing II: Producers $\rightarrow$ Retailers $\rightarrow$ Consumers

Marketing III: Producers $\rightarrow$ Commission agents $\rightarrow$ Local traders $\rightarrow$ Wholesalers $\rightarrow$ Retailers $\rightarrow$ Consumers

Marketing IV: Producers $\rightarrow$ Local traders $\rightarrow$ Wholesalers $\rightarrow$ Retailers $\rightarrow$ Consumers

Marketing V: Producers $\rightarrow$ Wholesalers $\rightarrow$ Retailers $\rightarrow$ Consumers

Marketing VI: Producers $\rightarrow$ Local traders $\rightarrow$ Wholesalers $\rightarrow$ Consumers

The estimated 5057.5 quintals of potato were marketed by sampled producers in 2015/16. Farmers use all channels to sell potato; however, the most widely used were channel-II and III. Higher quantity was purchased by commission agents and local traders. The overall marketing channels are simple and linked producers with other actors. In Masha district about 83\% of potato was sold to local traders. According to [6] in Kenya and Uganda about $87 \%$ and $66.67 \%$ of potatoes were sold to traders direct from the field, respectively, however, in some parts Ethiopia (in West and North shewa and Awi zones) most potato farmers took their produce piecemeal to village markets, often on horseback or hand carried, where it was sold to wholesalers. In (Figure 3) the orange line indicates institutions controlling potato marketing system; this is District Office of Custom and Revenue that monitors and regulates potato marketing in Masha by collecting taxes from traders and wholesalers (2Birr/ quintal). Black line shows flow raw farming materials supplied for producers, whereas, the light blue line represents the flow of potato produced by farmers. All producers and traders sell unprocessed potato; this limited number of marketing channels to be few. Processed potato entering into potato could increase marketing channels.

\section{Potato utilization pattern in the study area}

2Bulti means a potato product stayed for more than one day. The price of that product reduced by half.

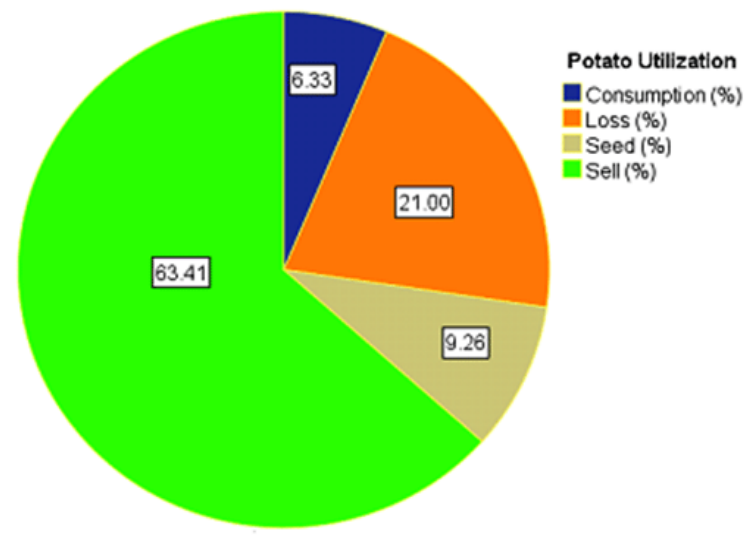

Figure 4: Potato utilization pattern of respondents
Potato produced in the study area was used for various purposes. (Figure 4) showed that majority $(63.41 \%)$ of potato was sold. However, the portion of potato consumed $(6.33 \%)$ in the study area was far less than the estimated portion in Sinan (34\%), Sol grow (18\%) (Kassa, 2014).And the result of Bezabih and Mengistu (2011) indicated that Hula (26\%), Shashemane (19\%), Saesi-Tsaeda Emba (10\%), Atsibi-Wonberta (9\%) of potato consumed.

\section{Relationship between producers and traders}

Different type of Relationships can exist between producers and traders. Relationships or linkages between producers and traders can be mapped according to basically 3 typologies:

Spot market relations: These are relations that are created 'on the spot', that means that actors make a transaction (including negotiations on price, volume and other requirements) with the duration and scope of that specific transaction. This is typical for transactions made on a fresh vegetables marketplace: buyer and seller meet, come to an agreement (or not) and break up the relationship. In related literature, these are also categorized as 'arm's length relationships'. In masha, $96 \%$ of producers responded that they had spot relationship with traders.

Persistent network relations: When actors have a preference for transacting with each other time and time again, we can speak of a persistent network relation. This comes with a higher level of trust and some level of interdependence. This relation can be formalized by contracts, but this is not a necessary. In the study area, $7.4 \%$ of producers responded that they had persistent network relations with traders.

Horizontal integration: This actually goes beyond the definition of a 'relationship', since both actors share the same (legal) ownership. One and the same organization (this can be an enterprise, or a cooperative) deals with different processes throughout the value chain. The ownership structure can be partial or full. In the study area, no producers shared this type of relationships with traders.

\section{Distribution of value addition along major potato value chain actors}

Each of the potato value chain actors adds value to the product as the product passes from one actor to another. In a way, the actors change the form of the product through packaging or transporting to other places (place utility).Value addition is the difference in sales price and cost of inputs (raw materials) at each stage of the value chain (Bezabih E. and Mengistu N., 2011). Potato producers in Masha district added $13.5 \%$ of the total value of potato in the Woreda. Local traders were responsible for 25.2 $\%$ of value addition while wholesalers and Retailers add about 27.5 and $32.7 \%$ of the value respectively. The highest profit was earned by retailers due to high selling price. 


\begin{tabular}{|c|c|c|c|c|c|}
\hline Particulars & Producer & Commission agents & Local trader & Wholesaler & Retailer \\
\hline Selling price Birr/qt & 395.608 & 415.987 & 552.204 & 663.404 & 701.729 \\
\hline Cost (Birr) & 158.7 & 395.608 & 56.2 & 121.9 & 57.7 \\
\hline Gross value added & 236.9 & 20.379 & 496.004 & 541.504 & 644.029 \\
\hline \% of total value added & 12.2 & 1.1 & 25.58 & 27.92 & 33.2 \\
\hline
\end{tabular}

\section{Potato Value chain performance}

The survey result showed that $56.377 \%, 22.315 \%, 15.846 \%$ and $5.462 \%$ of the final consumer's price is shared by producers, local traders, wholesalers and retailers respectively. The marketing margin of producers and local traders in the study area was higher than marketing margin of producers and collectors in eastern Ethiopia which was 45.88 and $20.81 \%$ respectively. But the marketing margin of other actors in eastern Ethiopia was higher than marketing margin of study area [14]. The profit gained by producers, local traders, wholesalers and retailers was 199.125, 483.814,564.814 and 641.889 birr/qt respectively. The profits gained from potato value chain in the study area were higher than that of eastern Ethiopia which was 38.00, 111.87, 189.84 and 202.65 birr respectively [14]. Each of the potato value chain actors adds value to the product as the product passes from one actor to another. In a way, the actors change the form of the product through packaging or transporting to other places (place utility).Potato producers in Masha district added 10.537 $\%$ of the total value of potato in the worded. This result is similar with the finding of (Kassa, 2014). Local traders were responsible for $25.603 \%$ of value addition while wholesalers and Retailers add about 29.89 and $33.97 \%$ of the value respectively (Figure 5). The finding of Bezabih and Mengistu (2011) revealed that Potato producers in Hulla worded added $24 \%$ of the total value of ware potato in the worded. Retailers are responsible for $59 \%$ of the value while wholesalers add about $17 \%$.The highest profit was earned by retailers due to high selling price and low operational costs. The analysis of value addition shows that all actors have added a significant value. This is in line with the finding of [15].

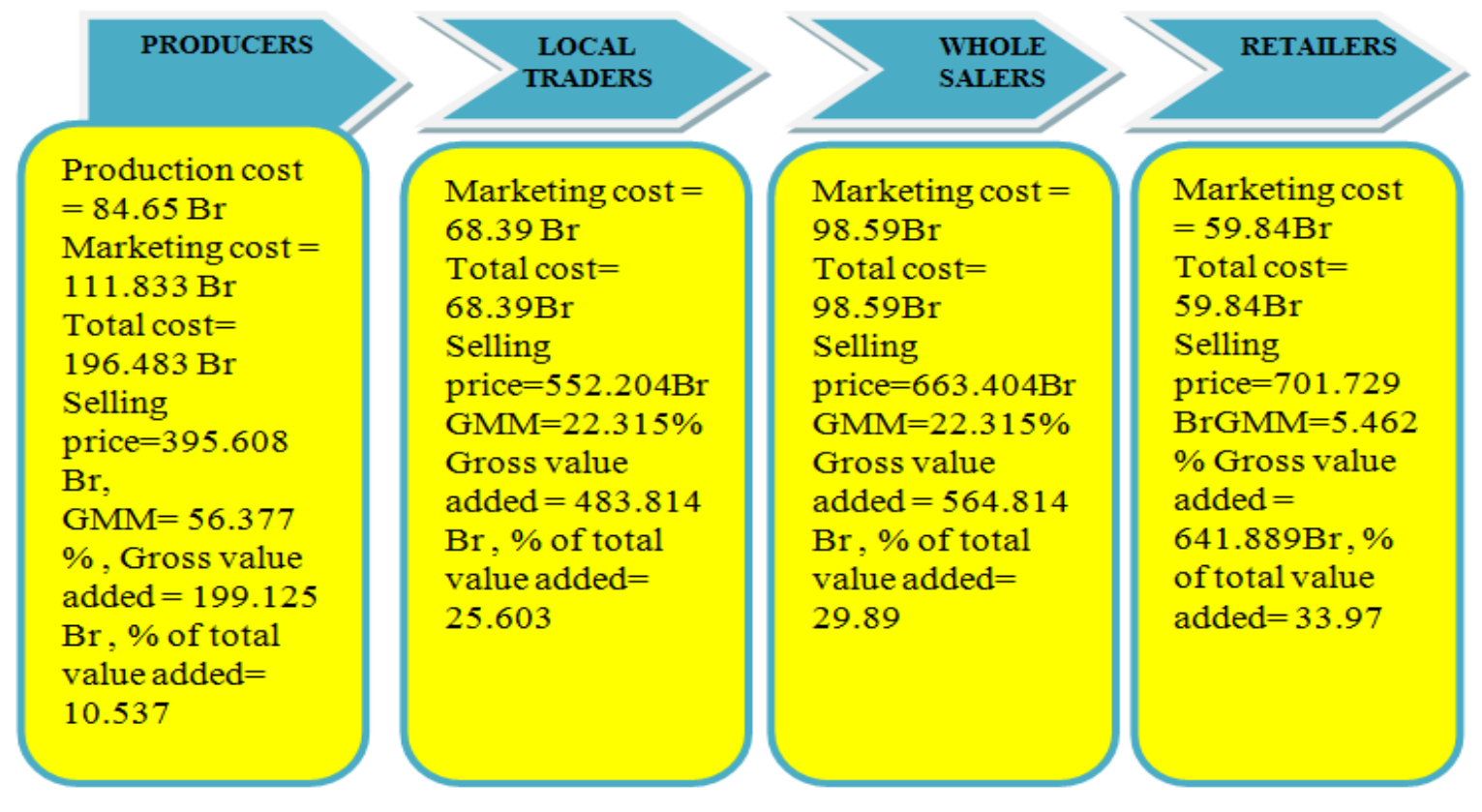

Figure 5: Marketing margin, profit and distribution of value addition along value chain actors

In the study area the benefit/cost $(\mathrm{B} / \mathrm{C})$ ratio is greater than 1 for all actors in potato value chain which was 1.03 for producers,7.07 for local traders,5.7 for wholesalers and 10.72 for retailers which revealed that retailers and local traders were highly profitable than other actors especially producers. Therefore, traders create less wealth in the chain than other actors. This is in line with the finding of [15].Generally, for B/C greater than 1, the business is profitable [15]Potato production is profitable for all actors along the chain, although there are wide disparities in earnings as different actors are subject to sitespecific market conditions, constraints, and circumstances.

\section{Constraints facing potato value chain actors}

There are different problems identified in focus group discussion, key informant interview and personnel observation. These problems are listed in(Figure 6).Value chain study 
conducted on off-season vegetables by [16] in Nepal indicated that the subsector faces some challenges such as unavailability of quality planting materials, lack of knowledge among the producers of the proper usage of fertilizers and pesticides as well as poor soil fertility management, lack of irrigation facilities, labor shortage, postharvest loss due the perishable nature of vegetables, limited access to reliable market information, unorganized market center, limited collection centers, and lack of proper packaging and transportation facilities.

Horticulture value chain study conducted in Eastern parts of Ethiopia identified different problems on the chain [17]. The major constraints of marketing identified by the same study include lack of markets to absorb the production, low price for the products, large number of middlemen in the marketing system, lack of marketing institutions safeguarding farmers' interest and rights over their marketable produces (e. g. cooperatives), lack of coordination among producers to increase their bargaining power, poor product handling and packaging, imperfect pricing system and lack of transparency in market information communications. [18] used value chain approach to study the competitiveness of Ethiopian coffee in the international market. The study indicates that Ethiopian farmers have low level of education, large family size with small farmland and get only $3 \%$ of the retail price in the German market.

Value chain study conducted on mango by [19] indicated that the subsector faces some challenges. Among others: highly disorganized and fragmented industry with weak value chain linkages, long and inefficient supply chains, inadequate information flows and lack of appropriate production are explained as the major problems.

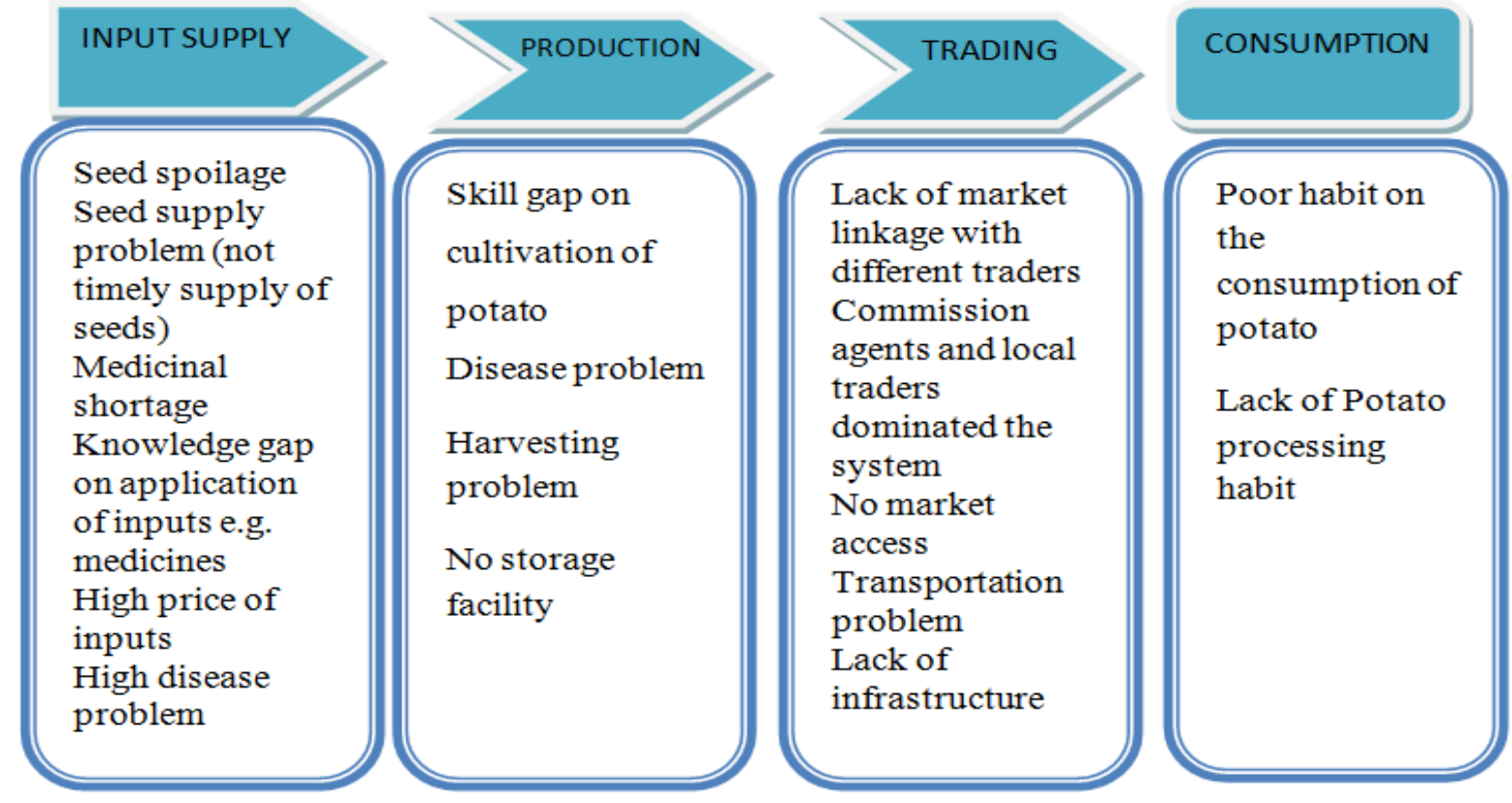

Figure 6: Constraints along potato value chain actors

\section{Conclusion}

The primary actors in potato value chain in Masha district were seed and other input suppliers, farmers, traders and consumers. The major value chain functions that vegetable growers perform include planting, fertilization, weeding, pest/disease controlling, harvesting, post harvest handling and transporting to selling areas. As product moves along different value chin routes each actor adds value. The average land holding size of producers in the study area was about 3.15 hectare per household. Of which about $0.57 \mathrm{ha}$ /household were allocated for potato production. The survey result showed that $56.377 \%, 22.315 \%, 15.846 \%$ and $5.462 \%$ of the final consumer's price is shared by producers, local traders, wholesalers and retailers respectively. The profit gained by producers, local traders, wholesalers and retailers was 199.125, 483.814,564.814 and 641.889 birr/qt respectively. Each of the potato value chain actors adds value to the product as the product passes from one actor to another. Potato producers in Masha district added $10.537 \%$ of the total value of potato in the worded. Local traders were responsible for $25.603 \%$ of value addition while wholesalers and Retailers add about 29.89 and $33.97 \%$ of the value respectively. The analysis of value addition shows that all actors have added a significant value. In the study area the benefit/cost $(\mathrm{B} / \mathrm{C})$ ratio is greater than 1 for all actors in potato value chain which was 1.03 for producers, 7.07 for local traders, 5.7 for wholesalers and 10.72 for retailers which revealed that retailers and local traders were highly profitable than other actors especially producers. Therefore, traders create less wealth in the chain than other actors. The major constraints of potato value chain actors in the study area were 
seed spoilage, seed supply problem (not timely supply of seeds), medicinal shortage, knowledge gap on application of inputs e.g. medicines, high price of inputs, high disease problem, skill gap on cultivation of potato, harvesting problem, no storage facility, lack of market linkage with different traders commission agents and local traders dominated the system, no market access, and transportation problem, lack of infrastructure, poor habit on the consumption of potato and lack of potato processing habit.

\section{References}

1. World Bank. Agri-business in Africa: removing barriers to regional trade to food staples, 2013.

2. Jerven M. Poor numbers: how we are misled by African development statistics and what to do about it. Ithaca, NY: Cornell university press, 2013.

3. Kaplinsky R, Morris M. A handbook for value chain research. Brighton, United Kingdom, 2001.

4. FAO (Food and Agriculture Organization). Developing Sustainable Food Value Chains: Guiding Principles. Food and Agriculture Organization of the United Nations (FAO), Rome, 2014.

5. CSA (Central Statistical Agency). The Federal Democratic Republic of Ethiopia Central Statistical Agency Agricultural Sample Survey Volume V.Report on Area, Production and Farm Management Practice of Belg Season Crops ForPrivate Peasant Holdings, 2016.

6. Gildemacher PR. Innovation in seed potato systems in eastern Africa. Thesis submitted in fulfillment of the requirements for the degree of doctor at Wageningen University, 2012.

7. Bezabih E, Mengistu N. Potato value chain analysis and development in Ethiopia. Case of Tigray and SNNP regions. International potato center (cipethiopia), 2011;

8. Hirpa A, Meuwissen MPM, Tesfaye A, Lommen WJM, Lansink AO, Tsegaye A, et al. Analysis of seed potato systems in Ethiopia. American journal of potato research. 2010;87(6):537-552.

9. Haggblade S, Veronique T, John S, Nango D, Diallo B. A conceptual framework for promoting inclusive agricultural value chains: prepared for the international fund for agricultural development (ifad). Michigan state university, department of agricultural, food and resource economics, 2012.
10. KIT, Faida Mali and IIRR. Chain empowerment: Supporting African farmers to develop market. Royal Tropical Institute, Amsterdam; Faida Market Link, Arusha; and International Institute of Rural Reconstruction, Nairobi, 2006.

11. Mekdes Dessie, Teshale Woldeamanuel, Getachew Mekonnen 2017. Market Chain Analysis of Red Pepper: The Case of Abeshge District, Guragie Zone, South Ethiopia. American Journal of Environmental and Resource Economics, 2017;2(2):62-72. doi: 10.11648/j. ajere.20170202.12

12. Kassa T, Alemu. Potato value chain in Ethiopia: Cases of Sinan and Bibugn Districts in East Gojjam, 2014.

13.SRM Janssens, SG Wiersema, H Goos, W Wiersma. The value chain for seed and ware potatoes in Kenya, Opportunities for development, 2013.

14.Eyasu E, van Beek C.L. Scaling innovations and Agricultural Best practices in Ethiopia: Experiences and challenges. Proceedings of the CASCAPE national stakeholder conference, 23-24 April 2014, Addis Ababa, Ethiopia. CASCAPE project, Wageningen University and Research Centre (WUR), Wageningen, The Netherlands, 2014.

15. Bidogeza, JC, Afari-Sefa, V, Endamana, D, Tenkouano, A, Kane, GQ. Value chain analysis of vegetables in the humid tropics of Cameroon, 2016.

16. USAID (United States Agency for International Development). Value chain analysis of off-season vegetables sub-sector in Nepal. Nepal Economic Agriculture, and Trade Activity, 2011.

17. Bezabih Emana, Hadera Gebremedihin. Constraints and opportunities of horticulture production and marketing in Eastern Ethiopia. Dry Lands Coordination Group Report No 46, 2007.

18. Dereje Birhanu. Assessment of forest coffee value chains in Ethiopia: A case study in Kefa zone, Gimbo district. Agricultural Science and Resource Management in the Tropics and Subtropics (ARTS).German, 2007.

19. Dendena Getachew, Efrem Lema and Lema Belay. Fresh mango value chain analysis in Arbaminch area. Organization of value chain competency. Addis Ababa, Ethiopia, 2009. 